\title{
Lise Öğrencilerinin Depresyon ve Olumsuz Otomatik Düşüncelerinin Cinsiyet ile Akademik Başarı Açısından İncelenmesi a
}

\author{
Nergüz BULUT SERINN $^{\mathrm{b}, \mathrm{c}}$, Ferda AYSAN ${ }^{\mathrm{d}}$
}

Özet

$\mathrm{Bu}$ araştırmanın amacı, lise öğrencilerinde depresyon ve olumsuz otomatik düşüncelerin ne düzeyde olduğunu belirlemek, cinsiyet ile akademik başarılarına göre anlamlı farlılıklar olup olmadığını incelemektir. Araştırmanın diğer bir amacı da öğrencilerin depresyon ve olumsuz otomatik düşünceleri arasındaki ilişkiyi incelemektir. Araştırmada veri toplama aracı olarak Beck Depresyon ölçeği ve Geliştirilmiş Otomatik Düşünceler Ölçeği kullanılmıştır. Çalışmanın örneklemini 248'i kadın, 237'si erkek olmak üzere toplam 485 lise öğrencisi oluşturmaktadır. Verilerin analizinde, Bağımsız Örneklem t-testi ve Pearson Korelasyon Analizi teknikleri kullanılmıştır. Çalışmada elde edilen en önemli bulgulara bakıldığında; öğrencilerin orta düzeyde bir depresyona ve düşük düzeyde olumsuz düşüncelere sahip oldukları saptanmıştır. Kadın öğrencilerin olumsuz düşünceleri erkeklerden daha yüksek düzeyde bulunmuştur. Başarısız kadın öğrencilerin, başarısız erkek öğrencilere göre olumsuz düşünceleri arasında anlamlı farklılık görülmüştür. Öğrencilerin depresyon düzeyleri ile olumsuz otomatik düşünceleri arasında yükek düzeyde olumlu yönde anlamlı bir ilişki saptanmiştır.
Anahtar Kelimeler

Depresyon

Olumsuz Otomatik Düşünceler

Akademik Başarı

Lise Öğrencileri

Makale Hakkında

Geliş Tarihi: 01.10.2020

Kabul Tarihi: 26.03.2021

Doi: $10.18026 /$ cbayarsos. 803563

\section{An Investigation of High School Students' Depression and Negative Automatic Thoughts in Terms of Academic Achievement by Gender}

\begin{abstract}
The aim of this study is to determine the level of depression and negative automatic thoughts in high school students and to examine whether there are significant differences according to gender and academic achievement. Another aim of the study is to examine the relationship between students' depression and negative automatic thoughts. Beck Depression Scale and Developed Automatic Thoughts Scale were used as data collection tools in the research. The sample of the study consists of 485 high school students, 248 female and 237 male. Mean Analysis, Independent Sample t-test and Pearson Correlation Analysis techniques were used in the analysis of the data. When looking at the most important findings obtained in the study; it was found that the students had a moderate level of depression and a low level of negative thoughts. Depression score averages of female students are higher than male students, but no significant difference was found. Female students' negative attitudes were found to be higher than men. A highly positive significant relationship was found between students' depression levels and their negative automatic thoughts.
\end{abstract}

Keywords

Depression

Negative Automatic Thoughts

Academic Achievement

High School Students

About Article

Received: 01.10.2020

Accepted: 26.03.2021

Doi: 10.18026/cbayarsos. 803563

\footnotetext{
a Bu araştırma, birinci yazarın doktora tezinin bir bölümünden üretilmiştir.

b Dr., Lefke Avrupa Üniversitesi, Dr Fazıl Küçük Eğitim Fakültesi, Lefke, KKTC TR-10 Mersin, Türkiye. ORCID: 0000-0002-2074-3253.

c İletişim Yazarı: nserin@eul.edu.tr

d Dr., Dokuz Eylül Üniversitesi, Buca Eğitim Fakültesi, Buca, İzmir, Türkiye. ORCID: 0000-0003-1396-3183.
} 


\section{Giriş}

Depresyon, bireylerde mutsuzluğa, çaresizliğe, ümitsizliğe ve kötümserliğe yol açmaktadır. depresif bozukluk olarak tanımlanan psikolojik rahatsızlık, duygusal anlamda verilen bir tepkiden çok bireyin hayatını olumsuz etkileyen bir sendromdur. Böyle bir durumda birey çevresini de olumsuz etkileyebilmektedir (Öztürk ve Uluşahin, 2015). Depresyon ile ilgili yapılan çalışmalarda depresyonu arttıran psikolojik, sosyal ve ailesel etkenler, depresyon oluşumunda öncü olabilecek psikopatolojik etkenler, depresyonu ortaya çıkaran stresli yaşam koşulları gibi konular araştırma alanlarını oluşturmaktadır (Tamar ve Özbaran, 2004).

Depresyon oldukça yoğun bir değersizlik, endişe ve suçluluk hissinin yanı sıra insanlardan uzaklaşma, iştah kesilmesi ve uyku problemi gibi çeşitli sorunları da beraberinde getirebilmektedir (Davison ve Neale, 2013). Demirbağ (2013) depresyon kavramını fertlerde gerçekleşen bunaltı ve çöküntü şeklinde nitelendirmiştir. Depresyon, bireylerde mutsuzluğa, çaresizliğe, ümitsizliğe ve kötümserliğe yol açmaktadır. Beck (1976), mutlakiyetçi düşünme, küçültme, büyültme, aşırı genelleme, seçici soyutlama ve keyfi yordama gibi farklı hataları tanımlamıştır. Otomatik düşüncelerin kaynağını çeşitli etkenler oluşturmaktadır. Bu etkenlerden en önemlileri arasında bireylerin anne-baba tutum ve davranışları, yaşıtları ile olan etkileşimleri, karakter özellikler, inançları, bireyin geleceği hakkındaki sahip olduğü görüşler yer almaktadır (Türkçapar, 2008). Eryüksel ve Ergün (2003) ebeveyn ve çocuk etkileşiminde içselleştirilmiş inançları ve varsayımları olabilecekleri üzerinde durmaktadır.

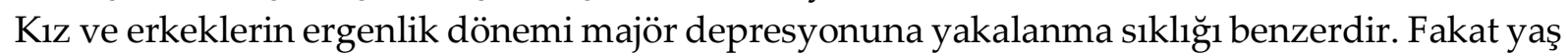
ilerledikçe kadınlarda depresyon daha sık görülmektedir (Çam ve Engin, 2014).

Beck (1976)'e göre depresif şemanın var olması bireyleri depresyona karşı zayıf ve korumasız yapmaktadır. Özgüven ve Sungur (1998) olumsuz düşüncelerin temelinde, bilişsel hataların önemli rol oynadığına vurgu yapmıştır. Depresif şemanın aktif olması ile olumsuz otomatik düşünceler üretilmekte ve bilişsel çarpıklıklar oluşmaktadır (Aysan ve Bozkurt, 2000). Olumsuz otomatik düşünceye sahip olmak depresyona temel oluşturmakta, depresif şemayı aktif kılacak şartların devam etmesi halinde depresif durum sürmektedir (Stiles ve Gotestam, 1989). Olumsuz otomatik düşünceler, kişinin dünya ve gelecek hakkında olumsuz yorum ve değerlendirmeler yapmasına neden olmaktadır. Bu durum da bireyde, kendini devamlı olarak olumsuz eleştiren bir şekle dönüşerek depresif duygu durumun ilerlemesine neden olmaktadır (Coyne ve Gotlib, 1983). Olumsuz inançlar aktif hale geldiğinde, otomatik olumsuz düşünceler zihni işgal etmeye başlar (Hjemdal, Stiles ve Wells, 2013). Otomatik düşüncelerin kaynağını oluşturan bazı etkenler bulunmaktadır. Bireyler gerek kendileri gerekse geleceği hakkında olumuz düşünceye sahip olmaları, onları ruhsal açıdan bunalıma karşı korumasız hale getirebildiği ve bunun sonucunda ortaya çıan psikolojik sorunların olumsuz otomatik düşüncelere ve depresif şemaların ortaya çıkmasına yol açabileceği ifade edilmektedir (Aysan ve Bozkurt, 2000; Bozkurt ve Aysan, 1998; Kahveci, 2016). Bilişsel hata; kesinliği hakkında yeterli bilgi olmayan verilerin yanlış bir biçimde işlenmesi şeklinde ifade edilmiştir. Otomatik düşüncelerle ortaya çıkan şemalar, bireyin kendi dünyasını kurması, çevresindeki bireyleri ve çevresini anlaması açısından önemlidir (Wenzel ve Cochran, 2006). İlgili literature incelendiğinde, son yıllarda depresyon ve otomatik düşünceleri ele alan çalışmalarda artış olduğu görülmektedir (Bozkurt, 2004; Bulut, 2007; Serin ve Aydınoğlu, 2011; Yavuzer ve Karataş, 2012; Serin, Özbulak ve Serin, 2012; Davison ve Neale, 2013; Demirbağ, 2013; Öztürk ve Uluşahin, 2015; Direktör, Şimsek ve Serin (2017); Duran, Karadaş ve Kaynak (2017); Sözlü ve Serin, 2019; Gül, Uçar, Sarp, Karaaslan ve Börekçi, 2014; Hjemdal, Stiles ve Wells, 2013. 
Karahan, Sardoğan, Özkamalı ve Menteş, 2016; Kurtoğlu, 2009; Küçük, 2019; Rana, Sthapit ve Sharma, 2017; Anlayışlı ve Serin, 2019; Özdemir, 2019; Anlayışlı ve Serin, 2020; Arı̆̆ ve Deniz, 2020 ).

Ergenlik döneminde bireylerin psikolojik sorunlarının daha az araştırıldığı ve ele alındığı bir yaş aralığını oluşturmaktadırlar. Ergenlik dönemindeki bireylere psikolojik sorunlarını çözmeleri için yardımcı olabilmek adına problemlerin ilişkili olduğu faktörler ve yaygınlığı incelenmesi gereği vurgulanmaktadır (Crocq, Bailey ve Guillon, 2003). Ergen, yetişkin bireye göre daha duyarlı olabilmektedir. Bu duyarlılığa bağlı olarak da riskli etkenlerden daha kolay etkilenebilir veya yaşadıklarından dolayı akılcı olamayan inanç ve düşünceler üretebilir (Ören ve Gençdoğan, 2007). Ergenlik dönemi içerisinde yer alan lise öğrencilerinde, depresyon ve olumsuz otomatik düşünceleri ele alan bu araştırma sonuçlarının özellikle lise döneminde bulunan ergenler arasında yaygın olduğu düşünülen depresif eğilimler ve olumsuz düşüncelerin azaltılması ve olumlu düşüncelerin artırılmasında önemlidir. Ergenlik döneminde olan öğrenciler, dönemin yarattığı duygusal nedenlerle okulda başarısız olabilmektedirler. Sürekli duygusal gerginlik yaşayan, kendi içine çekilen gencin okul başarısı olumsuzlaşabilir. Öğrencilerin okul başarısı ile depresif duygu durumları ve olumsuz düşüncelerini ortaya koyan çalışma sonuçları, öğrencilerde başarısızlığı önleyici psikolojik danışma çalışmalarında önemli ipucu vereceği düşünülmektedir.

$\mathrm{Bu}$ araştırmanın amacı, İzmir il merkezinde Milli Eğitim Bakanlığına bağlı liselerde öğrenim görmekte olan lise öğrencilerinde depresyon ve olumsuz otomatik düşüncelerin ne düzeyde olduğunu belirlemek ve cinsiyete ile akademik başarılarına göre anlamlı farlılıklar olup olmadığını incelemektir. Araştırmanın diğer bir amacı da depresyon ve olumsuz otomatik düşüncelerin arasındaki ilişkiyi incelemektir.

Bu genel amaç çerçevesinde aşağıdaki sorulara cevap aranmştır:

1.Lise öğrencilerinin depresyon ve olumsuz düşünceleri ne düzeydedir?

2.Lise öğrencilerinin cinsiyete göre, depresyon ve olumsuz otomatik düşüncelerinde anlamlı bir farklılık var midır?.

3.Lise öğrencilerinin akademik başarılarına göre, depresyon düzeyleri ve olumsuz otomatik düşünceleri arasında anlamlı bir farklılık var mıdır?.

4. Lise öğrencilerinin depresyon ve olumsuz otomatik düşüncelerin arasında anlamlı bir ilişki varmı dir?

\section{Yöntem}

\section{Araştırma Modeli}

Araştırma lise öğrencilerinin depresyon ve olumsuz otomatik düşüncelerini incelenmeye dönük betimsel bir çalışmadır. Tarama modelinin amacı bir durumu betimlemektir. Araştırılan olay, birey veya nesne değişiklik yapılmadan adlandırılmaya çalışılır. Etkileme mücadelesi olmaz. Gözlem yapıp belirlemeye önem verilir (Karasar, 2005).

\section{Evren ve Örneklem / Çalışma Grubu}

Araştırmanın evrenini İzmir il merkezinde bulunan lise öğrencileri oluşturmaktadır. Çalışmanın örneklemini ise bu liselerde eğitim gören 248'i kadın, 237'si erkek olmak üzere toplam 485 lise öğrencisi oluşturmaktadır. Çalışmada, örneklem seçiminde uygun örnekleme yöntemi kullanılmıştır. Öğrencilerin akademik başarılarının belirlenmesinde, öğrencilere 
öğrenim gördükleri son dönemde aldıkları kaç zayıf notu ve yüksek notu olduğu sorularak yazmaları istenmiştir.

\section{Veri Toplama Araçları}

Beck Depresyon Ölçeği (BDÖ): İlk kez Beck ve ark. (1961) tarafından geliştirilmiş olan BDÖ, 1978 versiyonu (Beck, Rash ve Shaw, 1979) ile hem kendini değerlendirmeye hem de kolay puanlamaya uygun hale getirilmiştir. Beck Depresyon Ölçeği, 0'dan 3'e kadar derecelendirilen, 21 maddeden oluşan kendini değerlendirme aracıdır. 21 maddenin her birinde 4 seçenek vardır. Derecelendirmelerin toplanmasıyla 0-63 arasında değişen toplam puan elde edilmektedir. Şiddet olarak; 0-9= Minimal, 10-16= Hafif, 17-29= Orta, 30-63= Şiddetli, şeklinde yorumlanmaktadır. Hisli (1988), yaptığı çalışmada, ölçeğin korelasyon katsayılarını, $\mathrm{r}=.80$ ve $\mathrm{r}=.74$ olarak bulmuştur (Akt.Hisli, 1989). Bu çalışmada ölçeğin kesme puanı 17 olarak alınmıştır.

Geliştirilmiş Otomatik Düşünceler Ölçeği (ODÖ-G): Kendall, Howard ve Hays (1989) tarafından geliştirilmiş olan Otomatik Düşünceler Ölçeği (Automatic Thoughts Questionnaire- Revised ATQ-R) kullanılmıştır. Ölçeğin ilk hali olan ve Hollon ve Kendall (1980) tarafından geliştirilmiş olan 30 maddelik Olumsuz Otomatik Düşünceler Ölçeğinin (Automatic Thoughts Questionnaire ATO-30) çeviri ve geçerlik-güvenirlik çalışması Hisli (1990); Aydın ve Aydın (1990) tarafından yapılmıştır. ATO-30 ölçeğine 10 olumlu cümlenin eklenmesiyle geliştirilmiş olan Otomatik Düşünceler Ölçeğinin geçerlik, güvenirlik çalışması Bozkurt (1998) tarafından yapılmıştır. Ölçeğin lise öğrencileri ile yapılan güvenirlik çalışmasında, ölçeğin Cronbach Alfa katsayısı ( $(\mathrm{r}=.92)$ ve iki yarım test güvenirlik katsayısı $\mathrm{r}=.82$ olarak bulunmuştur. Ölçekten alınan yüksek puan, olumsuz düşüncenin yüksekliğini göstermektedir.

\section{Verilerin Toplanması ve Analizi}

Araştırmada elde edilen veriler SPSS 23 (Statistical Package for Social Sciences) paket programı aracılığ 1 ile analiz edilerek tablolar haline getirilerek yorumlanmıştır. Veriler; dağılım analizi, Ortalama Analizleri, Bağımsız Örneklem ' $t$ ' testi ve ve Pearson Korelasyon Analizi teknikleri kullanılmıştır.

\section{Bulgular}

Çalışmanın bu bölümünde araştırmada elde edilen bulgular ve tablolara yer verilmiştir.

\section{Lise öğrencilerinin depresyon ve olumsuz otomatik düşünceleri ne düzeydedir?}

Tablo 1. Beck Depresyon Ölçeğinin Puan Aralıkları

\begin{tabular}{lc}
\hline BDÖ Puan Aralıkları & Düzey \\
\hline $0-9$ & Düşük Düzeyde Depresyon \\
$10-16$ & Orta Düzeyde Depresyon \\
$17 \leq$ & Yüksek Düzeyde Depresyon \\
\hline
\end{tabular}

BDÖ: Beck Depresyon Ölçeği

Tablo1' de görüldüğü üzere, Beck Depresyon Ölçeği (BDÖ) puan ortalamaları X=0-9 arasında düşük düzeyde depresyon, $X=10-16$ orta düzeyde depresyonu ve $X=17$ ve üzeri puan yüksek düzeyde depresyonu göstermektedir. 
Tablo 2. Olumsuz Otomatik Düşünceler Ölçeğinin Puan Aralıkları

\begin{tabular}{|c|c|c|}
\hline $\begin{array}{l}\text { ODÖ-G Puan } \\
\text { Aralıkları }\end{array}$ & \multicolumn{2}{|c|}{ Düzey } \\
\hline $40-93$ & \multicolumn{2}{|c|}{ Düşük Düzeyde Olumsuz Düşünce } \\
\hline 94-146 & \multicolumn{2}{|c|}{ Orta Düzeyde Olumsuz Düşünce } \\
\hline 147-200 & \multicolumn{2}{|c|}{ Yüksek Düzeyde Olumsuz Düşünce } \\
\hline \multicolumn{3}{|c|}{ ODÖ-G: Geliştirilmiş Olumsuz Otomatik Düşünceler Ölçeği } \\
\hline \multicolumn{3}{|c|}{$\begin{array}{l}\text { Tablo } 2 \text { incelendiğinde, Geliştirilmiş Olumsuz Otomatik Düşünceler Ölçeği (ODÖ-G } \\
\text { puanlanmasında, } X=40-93 \text { düşük düzeyde olumsuz düşünce, } X=94-146 \text { orta düzeyde olumsuz } \\
\text { düşünce ve } X=147-200 \text { yüksek düzeyde olumsuz düşünce düzeyini göstermektedir. }\end{array}$} \\
\hline \multicolumn{3}{|c|}{ Tablo 3. Lise Öğrencilerinin ODÖ-G ve BDÖ Puan Ortalamaları ve Standart Sapma Değerler } \\
\hline Ölçekler & $\bar{x}$ & ss \\
\hline ODÖ-G & 89.27 & 22.08 \\
\hline BDÖ & 14.33 & 8.17 \\
\hline
\end{tabular}

BDÖ:Beck Depresyon Ölçeği

Tablo 3'de görüldüğü üzere, katılımclların Geliştirilmiş otomatik düşünceler ölçeğinden aldıkları puanların ortalaması $(X=89.27$; ss=22.08)' dır.Katılımcıların depresyon ölçeğinden aldıkları puan ortalaması ise $(X=14.33$; ss=8.17) olarak bulunmuştur.

2.Lise öğrencilerinin cinsiyete göre, depresyon ve olumsuz otomatik düşüncelerinde anlamlı bir farklılık var mıdır?.

Tablo 4. Lise Öğrencilerinin Cinsiyet Bağımsız Değişkenine Göre ODÖ-G ve BDÖ Puan Ortalamaları, t-testi Sonucu

\begin{tabular}{|c|c|c|c|c|c|c|}
\hline \multirow{3}{*}{$\begin{array}{l}\text { Bağımlı } \\
\text { Değişkenler }\end{array}$} & \multicolumn{4}{|c|}{ Cinsiyet Bağımsız Değişkeni } & \multirow[t]{3}{*}{ t-Değeri } & \multirow[t]{3}{*}{ Önem Düzeyi } \\
\hline & \multicolumn{2}{|c|}{ Kadın $(n=248)$} & \multicolumn{2}{|c|}{ Erkek (n=237) } & & \\
\hline & $\bar{x}$ & ss & $\bar{x}$ & ss & & \\
\hline ODÖ-G & 91.87 & 24.02 & 86.55 & 21.33 & 2.57 & $\mathrm{p}<.05^{*}$ \\
\hline BDÖ & 14.92 & 8.30 & 13.71 & 8.01 & 1.63 & $\mathrm{p}>.05$ \\
\hline
\end{tabular}

${ }^{*} \mathrm{p}<.05$

Tablo 4'de görüldüğ̈̈ üzere, kadın öğrencilerin olumsuz otomatik düşünceleri erkek öğrencilerden daha yüksek düzeyde bulunmuştur $(\mathrm{t}=2.57, \mathrm{p}<.05)$.

3.Lise öğrencilerinin akademik başarılarına göre, depresyon düzeyleri ve olumsuz otomatik düşünceleri arasında anlamlı bir farklılık var mıdır?.

Tablo 5. Başarılı Lise Öğrencilerinin Cinsiyet Bağımsız Değişkenine Göre ODÖ-G ve BDÖ Puan Ortalamaları, t-testi Sonucu

\begin{tabular}{lccc}
\hline Bağımlı & Başarılı Lise Öğrencileri & t-Değeri & Önem Düzeyi \\
Değişkenler & Kadın $(n=128)$ & Erkek $(n=120)$ & \\
& &
\end{tabular}


Lise Öğrencilerinin Depresyon ve Olumsuz Otomatik Düşüncelerinin Cinsiyet ile Akademik Başarı Açısından İncelenmesi

\begin{tabular}{lcccccc}
\multicolumn{1}{c}{$\overline{\boldsymbol{x}}$} & ss & $\overline{\boldsymbol{x}}$ & ss & & \\
\hline ODÖ-G & 84.14 & 18.08 & 81.87 & 22.74 & .51 & $\mathrm{p}>.05$ \\
BDÖ & 12.53 & 6.69 & 12.08 & 7.32 & .85 & $\mathrm{p}>.05$ \\
\hline
\end{tabular}

Tablo 5 incelendiğinda genel akademik başarıları cinsiyet açısından ele alındığında başarılı kadın öğrencilerin, başarılı erkek öğrencilere göre olumsuz düşünceleri ve depresyon puan ortalamaları arasında anlamlı farklılık bulunmamıştır.

Tablo 6. Başarısız Lise Öğrencilerinin Cinsiyet Bağımsız Değişkenine Göre ODÖ-G ve BDÖ Puan Ortalamaları, t-testi Sonucu

\begin{tabular}{lcccccc}
\hline Bağımlı & \multicolumn{3}{c}{ Başarısız Lise Öğrencileri } & t-Değeri & Önem Düzeyi \\
Değişkenler & Kadın $(\mathrm{n}=120)$ & \multicolumn{2}{c}{ Erkek $(\mathrm{n}=117)$} & & \\
& $\overline{\boldsymbol{x}}$ & $\mathrm{ss}$ & $\overline{\boldsymbol{x}}$ & ss & \\
& 100.11 & 26.01 & 91.35 & 18.69 & 2.97 & $\mathrm{p}<.05^{*}$ \\
\hline ODÖ-G & 17.47 & 9.09 & 15.39 & 8.37 & 1.83 & $\mathrm{p}>.05$ \\
BDÖ & & & & & \\
\hline
\end{tabular}

${ }^{*} \mathrm{p}<.05$

Tablo 6'da görüldüğü üzere, genel akademik başarıları cinsiyet açısından ele alındığında başarısız kadın öğrencilerin olumsuz düşünceleri ile başarısız erkek öğrencilerin olumsuz düşünceleri arasında anlamlı farklılık bulunmuştur ( $\mathrm{t}=2.97, \mathrm{p}<.05)$.

4. Lise öğrencilerinin depresyon ve olumsuz otomatik düşüncelerin arasında anlamlı bir ilişki varmı dir?

Tablo 7. Lise Öğrencilerinin Olumsuz Otomatik Düşünceler Ölçeği ve Beck Depresyon Ölçeği Puanlarına İlişkin Pearson Momentler Çarpımı Korelasyon Katsayıları

\begin{tabular}{ccc}
\hline Ölçekler & Cinsiyet & BDÖ \\
\hline ODÖ-G & Kadın & $.68^{* *}$ \\
& Erkek & $.66^{* *}$ \\
BDÖ & Kadın & - \\
ODÖ-G & Erkek & - \\
\hline O*p<001 & & $.70^{* *}$
\end{tabular}

${ }^{* *} \mathrm{p}<.001$

Tablo 6 incelendiğinde, lise eğitimine devam eden kadın ve erkek öğrencilerin, Otomatik Düşünceler Ölçeği ve Beck Depresyon Ölçeği ile gösterdiği ilişki düzeyi kadınlar için (r=.68, $\mathrm{p}<.001)$ ve erkek öğrenciler için $(\mathrm{r}=.66, \mathrm{p}<.001)$ pozitif yönde ve anlamlı bir ilişkinin olduğu saptanmıştır. Lise eğitimine devam eden öğrencilerin genel olarak Otomatik Düşünceler Ölçeği ve Beck Depresyon Ölçeği ile gösterdiği ilişki düzeyi incelendiğinde ( $r=.70, p<.001)$ pozitif yönde anlamlı bir ilişkinin olduğu saptanmıştır. 


\section{Tartışma, Sonuç ve Öneriler}

Araştırma sonucunda, katılımcıların genel olarak düşük düzeyde olumsuz düşünceye ve orta düzeyde depresyona sahip oldukları görülmüştür. Anlayışlı ve Serin (2020) yaptıkları çalışmada lise öğrencileri orta düzeyde depresyona sahip bulunmuştur. Lise öğrencilerinin Geliştirilmiş Olumsuz Otomatik Düşünceler Ölçeği puan ortalaması, yurt dişında lise öğrencileri ile yapılan bazı çalışmalarda elde edilen puan ortalamasına göre düşük olduğu görülmüştür (Hollon ve Kendal, 1980). Lise öğrencilerinin Beck Depresyon Ölçeği puan ortalaması, Özben (1990)'in lise öğrencileri ile yaptığı çalışmada bulduğu BDÖ puan ortalamasından yüksek bulunmuştur. Bireylerin olaylar karşısında kontrollerinin olup olmadığına dair inançlarii, sahip oldukları olumsuz otomatik düşünceleri, olaylara verdikleri tepkileri yaşadıkları duyguyu etkilemektedir (Çivitci, 2016). Bilişsel yaklaşıma göre, yaşanılan duygusal zorlanmanın ve sorunların altında bireylerin sahip oldukları olumsuz otomatik düşünceler yatmaktadır (Akkoyunlu ve Türkçapar, 2013). Otomatik düşünceler, kelimeler ya da görüntüler şeklinde ortaya çıkabilmektedir (Yıldız, 2017). Reif ve Elster (1998)'e göre, ergenlik dönemindeki birey stresli durumlarla karşı karşıya geldiği süre boyunca depresyon riski de artmaktadır (Akt. Anlayışlı ve Serin, 2019). Ülkemizde özellikle lise son sinıflarda öğrenim gören öğrencilerin, üniversiye girişle ilgili kaygı düzeyleri, depresyon ve buna bağlı olarak olumsuz düşüncelerinin daha yüksek olacağı düşünülmektedir.

Çalışmada kadın öğrencilerin olumsuz otomatik düşünceleri erkek öğrencilerden daha yüksek bulunmuştur. Bulut (2007); Gül, Uçar, Sarp, Karaaslan ve Börekçi (2014); Karahan, Sardoğan, Özkamalı ve Menteş (2016); Direktör, Şimsek, ve Serin (2017); Özdemir (2019) olumsuz otomatik düşünceler ile ilgili yaptıkları çalışmalarda benzer bulgulara ulaşmışlardır. Bu çalışmanın bulguları ile paraleldir. Oruç (2013) yaptığ çalışmada hem erkeklerin hem de kadınların aynı aralıkta negatif otomatik düşüncelere sahip olduğunu belirtmektedir. Aysan ve Bozkurt (2000); Sözlü ve Serin (2019) ve Tümkaya, Çelik ve Aybek (2011) lise öğrencileri ile yaptıkları çalışmada cinsiyet değişkeni ile olumsuz otomatik düşünceleri arasında anlamlı bir farklılılık bulunmamıştır. Gül, Keskin ve Bozkurt (2014) olumsuz otomatik düşüncelerle cinsiyet arasında anlamlı fark olmadığını ancak kadınların daha yoğun bir şekilde olumsuz otomatik düşünceye sahip olduğunu bulmuşlardır. Kurtoğlu (2009) lise öğrencileri ile yaptığ çalışmada kadın öğrencilere oranla erkek öğrencilerin otomatik düşüncelerinin daha yüksek olduğunu bulmuştur. Kadın ve erkek öğrencilerin depresyon düzeyleri arasında anlamlı bir farklılık bulunmamıştır. Anlayışlı ve Serin (2019); Anlayışlı ve Serin (2020) yaptıkları araştırmada da kız öğrencilerin depresyon düzeyleri erkeklere göre anlamlı düzeyde yüksek bulunmuştur. Bu çalışmanın bulgularından farklıdır.

Genel akademik başarı açısından ele alındığında başarısız kadın öğrencilerin olumsuz otomatik düşünceleri erkek öğrencilerden daha yüksek düzeyde bulunmuştur. Kadın öğrencilerin depresyon puanları erkek öğrencilerden yüksektir, ancak aralarındaki fark istatistiksel olarak anlamlı bulunmamıştır. Başarısız öğrencilerin depresyon ve olumsuz düşünceleri, başarılı öğrencilerden daha yüksek düzeyde bulunmuştur. Aydın (1988) ve Özben (1990) yaptıkları çalışmalarında genel akademik başarı açısından başarısız öğrencilerin depresyon düzeylerini başarılı öğrencilerden daha yüksek düzeyde olduğunu bulmuşlardır. Özben (1990) okul başarısızlığının öğrencilerin depresyon düzeylerini artırdığını, depresyon düzeyi ile akademik başarısızlık arasında her zaman doğru yönde bir ilişki olabileceğini vurgulamıştır. $\mathrm{Bu}$ çalışmada başarısız kız öğrencilerin, başarısız erkek öğrencilere göre olumsuz düşünceleri arasında anlamlı farklılık bulunmuştur. Buna göre, başarısız kız 
öğrencilerin erkek öğrencilere göre daha fazla bilişsel çarpıtmalara sahip oldukları söylenebilir. Kapucı (2016) yaptığı çalışmada, başarısı düşük öğrencilerinin depresyon düzeylerinin daha yoğun olduğunu bulmuştur. Y1lmaz, Şahin, Haseski ve Erol (2014) üniversiteye hazırlanan lise öğrencilerinde devamsızlık, ilgisizlik ders dışı yönlere kaymaların başarısızlığa yol açtığını ifade etmiştir. Başarılı kadın öğrencilerin, başarılı erkek öğrencilere göre olumsuz düşüncelerinde ise depresyon puan ortalamaları arasında anlamlı farklılık bulunmamıştır. Anlayışlı ve Serin (2020) yaptıkları çalışmada lise öğrencilerinin depresyon düzeyleri ile akademik başarıları arasında anlamlı farklılıklar olduğu saptanmıştır. Akademik başarılarına göre, akademik başarıları çok kötü olan katılımcıların akademik başarıları iyi olan ve çok iyi olan katılımcllara kıyasla depresyon düzeylerinin anlamlı düzeyde yüksek olduğu gözlemlenmiştir.

Katılımcların depresyon düzeyleri ile olumsuz düşünceleri arasında pozitif ve anlamlı bir ilişki bulunmuştur. Depresyon düzeyi arttıkça olumsuz düşünceleri de aynı doğrultuda artmaktadır. Kadın ve erkek öğrenciler için pozitif yönde ve anlamlı bir ilişkinin olduğu saptanmıştır (Aytar, 1987; Aydın, 1988; Garber, Weis ve Shanley, 1993; Şahin ve Şahin, 1992) çalışmalarında benzer sonuçlara ulaşmışlardır. Aysan ve Bozkurt (2000) yaptıkları çalışmada, üniversite öğrencilerinin depresyon düzeyi ile olumsuz otomatik düşünceler arasında anlamlı düzeyde pozitif yönde ilişkili bulunmuştur. Bu sonuçlar eldeki çalışmanın bulgularını desteklemektedir

\section{Öneriler}

Araştırmanın sonuçları genel olarak değerlendirildiğinde, kız öğrencilerin olumsuz düşünceleri ve depresyon düzeyleri yüksek bulunmuştur. Ergenlik döneminin özelliklerini taşıyan lise öğrencilerin, özellikle de kadın öğrencilerin, olumsuz düşüncelerini ve depresyon düzeylerini azaltmaya dönük olarak, okul rehberlik servislerinde etkili psikolojik danışma programları düzenlenmelidir. Başarısız öğrencilerin depresyon ve olumsuz düşünceleri yüksektir. Öğrencilerin akademik başarılarını artırma konusunda yapılacak psikolojik danışma ve rehberlik çalışmaları ile depresyon ve olumsuz düşüncelerini azaltma yönünde önlemler alınabilir. Depresyon düzeyi artıkça, olumsuz düşünceler de aynı yönde artmaktadır. Okullarda öğrencilerle yapılacak psikolojik danışma oturumlarında olumsuz otomatik düşüncelerin yerine geçecek olan düşünce biçimlerinin öğrenilmesi için bilişsel yeniden yapılandırma tekniklerinin kullanıldığı yaklaşımların kullanılmasının yararlı olacağı düşünülmektedir. Bu çalışmada elde edilen sonuçların genellenmesinde bazı sınırlılıklar vardır. Öncelikle, örneklem depresyon tanısı konmamış öğrencilerden oluşmuştur. İkinci olarak elde edilen bulgular, nedensel sonuçlar olmaktan çok ilişkiseldir.

Gelecekte benzer konuda araştırma yapacak olan araştırmacıların, araştırmalarında boylamsal araştırma deseni kullanılarak yapılması uygun olabilir. Olumsuz otomatik düşünceler ve depresyonda, tükenmişlik ve sosyal kaygı gibi kavramların aracılık etkilerinin incelenmesi önerilebilir. Benzer çalışmaların farklı eğitim kademelerinde öğrenim gören öğrencilerle, farklı değişkenlerle, farklı yaş gruplarından öğrencilerle çalışılması önerilebilir. Özellikle günümüzde bir hayli önem kazanmış olan depresyonla ilişkili olduğu düşünülen, kaygı, stres ve olumsuz otomatik düşünceleri ele alan çalışmlara yapılması önerilebilir. Sözü edilen sınırlılıklara karşın elde edilen bulgular, depresyonu yordamada olumsuz otomatik düşüncelerin anlaşılması gerektiğini göstermektedir. Son olarak, bu çalışmadan elde edilen bulguların gelecekte yapılacak çalışmalara ışık tutacağına inanılmaktadır. 


\section{Kaynakça}

Akkoyunlu, S., \& Türkçapar, M. H. (2013). Bir teknik: Alternatif düşünce oluşturulması. Bilişsel Davranışçı Psikoterapi ve Araştırmalar Dergisi, 2(1), 53-59.

Anlayışlı, C., \& Serin, N. B. (2020). Lise öğrencilerinin depresyon düzeylerinin incelenmesi (KKTC Örneklemi). 3. Uluslararası Sosyal Bilimleri Kongresi (USBIK 2020)". 29-31 Ocak 2020 Kayseri-TÜRKIYE. Kongre Tam Metin Kitabı. S.787-796.

Anlayışlı, C., \& Serin, N. B. (2019). Lise öğrencilerinde internet bağımlılı̆̆1 ve depresyonun cinsiyet, akademik başarı ve internete giriş süreleri açısından incelenmesi. Folklor/edebiyat, 25, 97-1, 753-767.

Arı̆̆, S., \& Deniz, M. E. (2020). Emotional intelligence and emotional expression as predictors of depression in university students. Turkish International Journal of Special Education and Guidance \& Counselling, 9(2), 98-108.

Aydın, G., \& Aydın, O. (1990). Otomatik düşünceler ölçeğinin geçerlik ve güvenirliği. Psikoloji Dergisi, 7(24), 51-55

Aysan, F., \& Bozkurt, N. (2004). Okul psikolojik danışmanlarının yaşam doyumu başa çıkma stratejileri ve olumsuz otomatik düşünceleri: İzmir ili örneği. XIII. Ulusal Eğitim Bilimleri Kurultayı. İnönü Üniversitesi, Eğitim Fakültesi, Malatya.

Aysan, F., \& Bozkurt, N. (2000). Bir grup üniversite öğrencisinin kullandığı başa çıkma stratejileri ile depresif eğilimleri ve olumsuz otomatik düşünceleri arasındaki ilişki. Marmara Üniversitesi Eğitim Bilimleri Dergisi, 12, 25-38.

Aytar, G. (1987). Depresyondaki düşünce bozukluklarının bilişsel kuram açısından incelenmesi (Yayımlanmamış Doktora Tezi). İstanbul Üniversitesi Sağlık Bilimleri Enstitüsü Psikiyatri Anabilim Dalı, İstanbul.

Beck, A. T. (1976). Cognitive therapy and the emotional disorders. New York: International Universities Press.

Beck, A. T., Rush, A. J., and Shaw, B. F. (1979). Cognitive therapy of depression. New York, Guilford.

Bozkurt, N. (2004). Bir grup üniversite öğrencisinin depresyon ve kaygı düzeyleri ile çeşitli değişkenler arasındaki ilişkiler. Ĕ̆itim ve Bilim Dergisi, 29(133), 52-59.

Bozkurt, N., \& Aysan, F. (1998). Bir grup üniversite öğrencisinin kullandığı başa çıkma stratejileri ile depresif eğilimleri ve olumsuz otomatik düşünceleri arasındaki ilişki. X. Ulusal Psikoloji Kongresi, Ankara.

Bulut, N. (2007). Okul psikolojik danışmanlarının yaşam doyumu, stresle başaçıkma stratejileri ve olumsuz otomatik düşünceleri arasındaki ilişkiler. Türk Psikolojik Danışma ve Rehberlik Dergisi, 3(27), 1-11.

Coyne, J. C., \& Gotlib, I. H. (1983). The role of cognition in depression: a critical appraisal. Psychological bulletin, 94(3), 472.

Çam, O., \& Engin, E. (2014). Ruh sağhlğ̆ı ve hastalıkları hemşireliği. İstanbul: İstanbul Tıp Kitabevi. 
Crocq, M. A., Leclercq, P., Guillon, M. S., \& Bailey, P. E. (2003). Olanzapina al descubierto en trastorno obsesivocompulsivo resistente al tratamiento antidepresivo. European Psychiatry Spanish edition, 10(2), 130-131.

Çivitci, A. (2016). Ergenler için mantık dışı inançlar ölçeğinin geliştirilmesi: Geçerlik ve güvenirlik çalışmaları. Türk Psikolojik Danışma ve Rehberlik Dergisi, 3(25), 69-80.

Davison, G., \& Neale, J. (2013). Abnormal psychology. Ringbound: Wiley.

Demirbağ, E. (2013). Depresyonun sağaltımında sorun çözme eğitiminin etkililiği. Yayımlanmamış Yüksek Lisans Tezi, Adnan Menderes Universitesi, Sağlık Bilimleri Enstitüsü, Psikiyatri Anabilim Dalı, Aydın.

Direktör, C., Şimsek, A. H., \& Serin, N. B. (2017). Negative automatic thoughts, emotional intelligence and demographical different variables affecting university students. College Student Journal, 51(3), 391-397.

Eryüksel, G. N., \& Akün, E. (2003). Depresyonu olan ergenler ile ana-babalarının aile ilişkilerinin ve bilişsel çarpıtmalarının incelenmesi. Türk Psikoloji Dergisi, 18(51), 59-73.

Hisli, N. (1989). Beck Depresyon Envanteri'nin üniversite öğrencileri için geçerliği güvenirliği. Psikoloji Dergisi. 7,3-13.

Hisli, N. (1990). Otomatik düşünceler ölçeğinin üniversite öğrencileri için geçerliliği ve güvenirliği. Psikoloji-Seminer Dergisi, (Özel sayı)8, 527-539.

Hollon, S. D., \& Kendal, P. C. (1980). Cognitive self-statements in depression: Development of an automatic thought questionnaire. Cognit Ther Res 4, 383-395.

Hjemdal, O., Stiles, T., \& Wells, A. (2013). Automatic thoughts and meta-cognition as predictors of depressive or anxious symptoms: A prospective study of two trajectories. Scandinavian Journal of Psychology, 54(2), 59-65.

Garber, J., Weiss, B., \& Shanley, N. (1993). Cognitions, depressive symptoms, and development in adolescents. Journal of Abnormal Psychology, 102(1), 47-57. https://doi.org/10.1037/0021843X.102.1.47

Gül, A. İ., Uçar, M., Sarp, Ü., Karaaslan, Ö., \& Börekçi, E. (2014). Miyofasyal ağrı sendromu ve sağlık anksiyetesi arasındaki ilişki. Uluslararası Klinik Araştırmalar Dergisi, 2(3), 89-92.

Gül, A. I., Keskin, D., \& Bozkurt, G. (2014). Tükenmislik sendromu ile otomatik düsünceler arasindaki iliski. Anadolu Psikiyatri Dergisi, 15(2), 93-98.

Kahveci, G. (2016). School counseling and students with disabilities. International Online Journal of Primary Education, 5(2), 15-21.

Kapuc1, Ö. (2016). Üniversite öğrencilerinin depresyon ve anksiyete düzeylerinin internet kullanım amaçları ve akademik başarı açısından incelenmesi (Yayınlanmamış Yüksek Lisans Tezi). İstanbul: Beykent Üniversitesi Sosyal Bilimler Enstitüsü.

Karahan, T. F., Sardoğan, M. E., Özkamalı, E., \& Menteş, Ö. (2016). An investigation of social efficacy expectancy and automatic thoughts in high school students according to the living places, and gender. Türk Psikolojik Danışma ve Rehberlik Dergisi, 3(26), 35-45.

Karasar, N. (2005). Bilimsel araştırma yöntemi. Ankara: Nobel Yayıncılık. 
Karim, J., \& Shah, S. H. (2014). Ability emotional intelligence predicts quality of life beyond personality, affectivity, and cognitive intelligence. Applied Research in Quality of Life, 9(3), 733-747.

Kurtoğlu, E. (2009). Lise öğrencilerinde gözlenen saldırganlık düzeylerinin otomatik düşünceler, cinsiyet ve sınıf düzeyi açısından incelenmesi (Yayınlanmamış Yüksek Lisans Tezi). Ondokuzmayıs Üniversitesi, Sosyal Bilimler Enstitüsü, Samsun.

Küçük, V. (2019). Üniversite öğrencilerinde sosyal kaygının yordayıcısı olarak ailesel bilişsel ve kişisel faktörler (Yayınlanmamış Doktora Tezi). Lisansüstü Eğitim Enstitüsü.

Ören, N., \& Gençdoğan, B. (2007). The analysis of the depression levels of the lycee students according to some variables. Kastamonu Eğitim Dergisi, 15, 85-92.

Oruç, T. (2013). Üniversite öğrencilerinde psikososyal değişkenlere göre yalnızlık ile otomatik düşünceler ilişkisinin incelenmesi (Yayımlanmamış Yüksek Lisans Tezi). Dokuz Eylül Üniversitesi, Eğitim Bilimleri Enstitüsü, İzmir.

Özben, Ş. (1990).Yurt dışından dönen işçi çocuklarının uyum problemlerinin okul başarılarına etkisi ve Türkiye'de yetişen öğrencilerle karşılaştırılması (Yayımlanmamış Doktora Tezi). Dokuz Eylül Üniversitesi, Eğitim Bilimleri Enstitüsü, İzmir.

Özdemir, B. (2019). Ortaokul öğrencilerinin problem çözme becerilerinde otomatik düşüncelerinin ve karar verme stillerinin rolü. Yayımlanmamış Yüksek Lisans Tezi, Maltepe Üniversitesi, Sosyal Bilimler Enstitüsü, İstanbul.

Özgüven, H. D., \& Sungur, M. Z. (1998). Sosyal fobi. Türk Psikiyatri Dergisi, 9(2), 128-138.

Öztürk, M. O., \& Uluşahin, A. (2015). Mental health and disorders. Ankara: Psychiatric Society Journal, 11, 6-30.

Reif, C. J., \& Elster, A. B. (1998). Adolescent preventive services. Primary care, 25(1), 1-21.

Serin, N. B., Serin, O., \& Özbaş, L. F. (2010). Predicting university students' life satisfaction by their anxiety and depression level. Procedia-Social and Behavioral Sciences, 9, 579-582.

Serin, N. B., Özbulak, B. E., \& Serin, O. (2012). The relationships among negative thoughts, problem solving and social skills of school psychological consultants. Eğitim Araştırmaları Dergisi, 12(49 A), 67-82.

Serin, N. B. \& Aydınoğlu, N. (2011). Relationships among life satisfaction, anxiety and automatic thoughts of candidate teachers. Education Sciences, 6(1), 1335-1343.

Sözlü, E., \& Serin, N. B. (2019). Lise öğrencilerinde olumlu ve olumsuz otomatik düşüncelerin farklı değişkenler açısından ıncelenmesi (Kuzey Kıbrıs Örneklemi). International Journal of New Trends in Arts, Sports \& Science Education (IJTASE), 8(3), 85-94.

Stiles, T. C., \& Götestam, K. G. (1989). The role of automatic negative thoughts in the development of dysphoric mood: An analogue experiment. Cognitive Therapy and Research, 13(2), 161-170.

Şahin, N. H., \& Şahin, N. (1992). Adolescent guilt, shame, and depression in relation to sociotropy and autonomy. In The World Congress of Cognitive Therapy, Toronto (pp. 17-21).

Rana, M., Sthapit, S., \& Sharma, V. D. (2017). Assessment of automatic thoughts in patients with depressive 1llness at a tertiary hospital in Nepal. Journal of the Nepal Medical 
Association, 56(206), 248-255.

Tamar, M., \& Özbaran, B. (2004). Çocuk ve ergenlerde depresyon. Klinik Psikiyatri, 2(1), 84-92.

Tümkaya, S., Çelik, M., \& Aybek, B. (2011). Lise öğrencilerinde boyun eğici davranışlar otomatik düşünceler umutsuzluk ve yaşam doyumunun incelenmesi. Çukurova Üniversitesi Sosyal Bilimler Enstitüsü Dergisi, 20(2), 77-94.

Yavuzer, Y., \& Karataş, Z. (2012). Ergenlerde otomatik düşünceler ile fiziksel saldırganlık arasındaki ilişkide öfkenin aracı rolü. Türk Psikiyatri Dergisi, 23, 1-7.

Türkçapar, M. H. (2008). Bilişsel terapi: Temel ilkeler ve uygulama (3. Bask1). Ankara: HYB yayıncilik.

Wenzel, A., \& Cochran, C. K. (2006). Autobiographical memories prompted by automatic thoughts in panic disorder and social phobia. Cognitive Behaviour Therapy, 35(3), 129-137.

Vandervoot, D. J., \& Skorikov, V. B. (2002). Physical healt and social network characteristics as deter-minants of mental health across cultures. Currrent Psychology, 21(1), 50- 68.

Yıldız, M. (2017). Üniversite öğrencilerinde fonksiyonel olmayan tutumların ve olumsuz otomatik düşüncelerin depresyona etkisi. Ulusal Eğitim Akademisi Dergisi, 1(1), 1-7.

Yılmaz, E., Şahin, Y. L., Haseski, H. İ., \& Erol, O. (2014). Lise öğrencilerinin internet bağımlılık düzeylerinin çeşitli değişkenlere göre incelenmesi: Balıkesir ili örneği. Ĕ̆itim Bilimleri Araştırmaları Dergisi, 4(1), 133-144. 